\title{
CAUSES OF CORRUPTION: EVIDENCE FROM SUB-SAHARAN AFRICA
}

\author{
Joseph Ato Forson ${ }^{1}$ \\ Graduate School of Public Administration, National Institute of Development Administration, \\ Thailand
}

\section{Theresa Yaaba Baah-Ennumh}

Department of Planning, Kwame Nkrumah University of Science and Technology, Ghana

\section{Ponlapat Buracom}

Graduate School of Public Administration, National Institute of Development Administration, Thailand

\section{Guojin Chen}

Wang Yanan Institute for Studies in Economics, Xiamen University, China

\section{Zhen Peng}

School of Management, Guangdong University of Technology, China

Accepted: Augustus 2016

\begin{abstract}
This study explores the causes of corruption in 22 countries in sub-Saharan Africa from 1996 to 2013. The sources of corruption are grouped into three main thematic areas - historical roots, contemporary causes and institutional causes to make way for subjective and objective measures. The subjective measures allow for assessment of the effectiveness of anticorruption policies. Using pooled OLS, fixed-effect and instrumental-variable approaches, and focusing on the perceived level of corruption as the dependent variable, we find that ethnic diversity, resource abundance and educational attainment are markedly less associated with corruption. In contrast, wage levels of bureaucrats and anticorruption measures based on government effectiveness and regulatory quality breed substantial corruption. Press freedom is found to be variedly associated with corruption. On the basis of these findings, we recommend that the fight against corruption on the continent needs to be reinvented through qualitative and assertive institutional reforms. Anticorruption policy decisions should focus on existing educational systems as a conduit for intensifying awareness of the devastating effect of corruption on sustainable national development.
\end{abstract}

Key words: corruption, sustainable development (SD), institutional quality, sub-Saharan Africa (SSA), governance

JEL: CO, I38, K4

\section{$1 \quad$ Introduction}

The debate seeking to account for sub-Saharan Africa's development challenges has been ongoing for the last two decades. Development economists, political heads and political scientists have in no small way attempted to contribute to finding the right mix of factors that best explains the plight of the subcontinent. Among the factors considered, the devastating effect of corruption on the well-being of sub-Saharan Africa's peoples cannot be overemphasized (Rose-Ackerman, 1999b; Rose-Ackerman, 1999a). As a result, countless efforts have gone into strategies to combat corruption. Such efforts have been made against the backdrop that institutional quality precedes all national development. According to Jain (2002), aid efforts, sound policies, as well as wellintentioned incentives may be less relevant unless offered in an environment that encourages selfsustaining development. 
This notwithstanding, there is a growing stream of conceptual and empirical research on the causes and consequences of corruption across countries in recent times (Pellegrini, 2011; Asongu, 2013; Dong \& Torgler, 2013; Treisman, 2000; Mauro, 1995; Forson, 2016). Although there appears to be an emerging consensus on the sources of corruption, the complexity of the topic gives rise to a number of critical issues that warrant attention. To begin with, there is a lack of agreement on how to measure and quantify the effect of institutions on controlling corruption (Billger \& Goel, 2009). Moreover, there is the impression that corruption controls can only be gauged from a subjective perspective. Nevertheless, with the emergence of the governance indicators, it becomes quite straightforward to assess the proactivity of administrative machinery in the fight against corruption. Strong institutions define the incentive for engagement, but the opposite could also be true. Anticorruption policies originate from strong institutions; hence institutions dictate the extent of social behaviour that is essentially linked to corrupt practices. Social behaviour is thus generally seen as "the rules of the game" as defined by institutions. Underpinned by this notion, the present paper identifies institutional ineffectiveness as an emerging source of corruption.

The contribution of this paper to the literature on corruption lies in supplementing the sources of corruption from the perspective of institutional ineffectiveness. We supplement the conventional factors in contemporary literature with ones that are institutionally embedded in order to answer the question whether the traditional sources of corruption hold in the face of effective corruption controls in sub-Saharan Africa. We assume that, if the quality of institutions could affect social behaviour and the incentive to fight corruption, the results of this paper could have significant implications for the literature on the determinants of corruption and, at the same time, shed further insight into the effectiveness of government machinery in dealing with this regional menace. This approach allows countries within the region to be assessed on the basis of common institutional characteristics.

The present paper is organised as follows. The next section (Section 2) reviews the existing body of literature on the theories of corruption. Data and methodology are presented and outlined in Section 3. This section further deals with the empirical findings and discusses these, within the context of the relevant theories, under the respective estimation strategies (namely pooled OLS, fixed-effect, and instrumental-variable approaches). Section 4 contains the conclusion and a discussion of policy direction.

\section{Related literature review}

\subsection{Theories of corruption}

In the seminal contribution of Jain (2002) on the causes of corruption, three fundamental preconditions are identified for corruption: bureaucratic discretionary power; the association of this power with economic rent; and deterrence, which has to do with the probability of being apprehended and punished. These preconditions can further be broadly categorised under costs and benefits, with the first two focusing variedly on the benefits of corruption, while the third deals with the cost of corruption (Becker, 1968; Dong \& Torgler, 2013).

Notwithstanding this, theories on the sources of corruption are manifold and have been widely used with, as their basis, economic and sociocultural principles. Yet, with the increasing importance attached to understanding the causes, others have contributed by supplementing these factors in both inductive and deductive studies. For instance, Dimant (2014) categorises the causes of corruption under economic and social factors. Other writers such as Wang (2005), in an attempt to diagnose the causes of corruption in China, have used a dual, broad-based terminology of social structural system and social cultural character. Though these categorisations are commendable, the present research argues that such delineations fail to acknowledge the impact of anticorruption policies on corruption. These policies, by extension, shape social behaviour.

Moreover, it is important to note that social behaviour (which accounts for social factors) is the antecedent of existing sets of rules. Rules, according to North (1990), originate from institutions. 
Put more formally, an institution is generally understood to be a representation of regularity in social behaviour agreed by members of a society, with such behaviour being specified in specific recurrent situations and being either self-policed or policed by some external authority (Schotter, 1981). By extension, the institution affects human activities by defining what people can do or how they interact with one another. Based on this reasoning, we have elected to reclassify some of the determinants under the so-called social factors within the institutional perspectives. This allows the study to group the theories of corruption under three perspectives: historical roots, contemporary causes, and institutional causes. The first two classifications invariably deal with the benefits of corruption, while the third classification is concerned more or less with the cost aspect. The study proceeds to discuss the theoretical and empirical linkages in the subsection that follows.

\subsubsection{Historical roots}

A central underlying factor that determines corruption, as argued in the literature, is rooted in historical connections, which have a profound significance for the current administrative and political landscape. Among these, the theory pertaining to the legal system seems to have practical significance in modern times. The theory explains that existing legal codes invariably affect the quality of government, including the level of control of corruption. Countries that have, in one way or another, been colonised in the past stand to have their legal codes influenced greatly by their colonisers. Glaeser and Shleifer (2002) indicate that historical antecedents, which largely trace the efforts of property owners to limit the discretionary power of the monarch, constitute the origin of common law legal codes. These authors, together with La Porta, Lopez-de-Silanes and Shleifer et al. (1999), further suggest that the legal systems in countries that adopted the British legal code will be conducive to better governance with lower levels of corruption.

Within the same historical context, there is a convergence of effects such that former British colonies have better civil-service codes owing to the influence of the British bureaucracy. The theory further explains that the British civil structure is premised on procedural aspects of the law, which enhances the capability of subordinates and judges to challenge hierarchies in order to enforce the law (Treisman, 2000). However, the method used to impose colonisation on these countries has been questioned, thereby undermining the positive effect that colonisation bestowed on the colonies. Critics of this theory argue that the British colonisers were interested in extracting resources and that the legal procedures established were designed to ensure that operations ran smoothly. Instead, the present paper maintain that there should be an empirical attempt to test the effects of colonisation on present-day corruption. Meanwhile, Mauro (1995) explains that a more ethnically fractionalised country tends to be more corrupt. The link that he endeavoured to establish was between ethno linguistic fractionalisation and corruption, based on the existence of alternative affiliations and obedience with respect to the state. Thus, in ethnically divided societies, civil servants and politicians will exploit their position so as to favour members of their particular ethnic group. In other words, divided societies tend to underprovide public goods, and this, in turn, augments the dependency on special bonds to obtain essential services from the state.

\subsubsection{Contemporary causes}

The contemporary perspective provides a better basis for objective measures of anticorruption policies than do theories on historical roots. First of all, income levels of countries may serve as a strong determinant of corruption in several ways. Richer countries can be expected to afford better institutions than poorer ones. Furthermore, many variables correlate with income, for instance schooling levels, urbanisation and access to mass media are associated with higher development levels and decrease the tolerance of the polity for corruption. Thus the relationship of real income to corruption can be expected to be negative.

Another theory embedded in the literature on rent-seeking emphasises the link between corruption and possibilities for economic agents to gain access to sources of higher-than-average rents when state intervention prevents free entry (Rose-Ackerman, 1999a). The fight against corruption is assisted by the reduction of non-generic state regulation and corruption will be 
determined by the magnitude of government activities (Acemoglu \& Verdier, 2000; Chaufen \& Guzman, 1999; Kotera, Okada \& Samreth, 2012). Related to this is the aspect of monopoly or restriction on imports, which creates opportunities for corruption by limiting the ability of citizens to choose from other goods and services (Vian, 2008). The supply of foreign products in the domestic market accordingly reduces rent-seeking and corruption by enhancing competition.

When viewed from an economic perspective, officials weigh up the costs and benefits of being corrupt and those of acting with integrity and then choose to act in a way that maximises their selfinterest (Jaen \& Paravisini, 2002). Corruption is more pervasive in situations where government agents or even private entities have monopoly power over clients. In other words, officials have a great deal of discretion or autonomy in making decisions, without adequate control being exercised over such discretion. There is thus insufficient accountability or government control is ineffective with regard to the outcomes of decisions (Vian, 2008; Klitgaard, 1988; Pellegrini, 2011). The monopoly thesis is further explained within the context of rent-seeking where economic agents gain access to sources of higher-than-average rents, especially when state intervention or policy prevents free entry (see Feinberg, 2009; Kolstad \& Søreide, 2009; RoseAckerman, 1999a; Søreide, 2002). Thus corruption is associated with the magnitude of government activities (Acemoglu \& Verdier, 2000; Chaufen \& Guzman, 1999).

Other theories also suggest that, at higher income levels or when additional income is obtained through legitimate means, corrupt practices could be less tempting because of the decreasing marginal utility of income (Schulze \& Frank, 2003; Forson \& Opoku, 2014). The wage levels of bureaucrats may also affect vulnerability in respect of corruption. Higher wages portend a higher cost when employment is lost, and a cost-benefit analysis suggests that higher wages provide an incentive to refrain from corruption (Becker, 1968; Treisman, 2000).

Other seminal contributions have in recent times identified foreign aid as a determinant of corruption in developing countries. In revealing this, Akurut (2013) inductively suggests that money in the form of foreign aid acts as a source of corruption. The main points of emphasis are foreign-aid money, the process involved in making such aid available, and how the aid is used. These assertions have been established empirically by Alesina and Dollar (2000) who have shown that aid inflow is weakly correlated with the development of beneficiary countries, but is strongly related to other elements such as cultural and historical proximity between donor and recipient countries. Similarly, a study by Ohler, Nunnenkamp and Dreher (2012) that sought to investigate whether the Millennium Challenge Corporation (MCC) was successful in promoting better control of corruption using the difference-in-difference-in-differences (DDD) approach found a strong anticipation effect soon after the establishment of the MCC. This increased uncertainty about the timing and amount of aid through the MCC, which appears to have weakened the incentive to fight corruption over time. Others authors have also argued that, since foreign aid is uncorrelated with the development of recipient countries, it is possible that such aid may be going elsewhere, thus fuelling corruption (see Burnside \& Dollar, 2000, 2004; Collier \& Dollar, 2002, 2004; Forson, Buracom, Baah-Ennumh \& Carsamer, 2015; Knack, 2013; Tavares, 2003).

Expanding on how rent-seeking can trigger corruption, proponents have identified naturalresource endowment as a source of corruption. According to them, natural resources are a common source of high rents available to those who have obtained the rights for exploration and extraction. It is further explained that these rents promote activities geared towards influencing policymakers who have power with regard to the distribution of exploitation rights, thus drawing away resources from other productive activities (Leite \& Weidmann, 1999).

A common variant identified in most studies and treated as a contemporary cause of corruption in the present study, is contemporary democracy. When contemporary democracy is considered from the procedural perspective of free elections and electoral competition, the association with corruption is less straightforward. Most indexes of democracy are based on the procedural aspects of democracy and have produced mixed empirical results. Studies making use of few controls have found contemporary democracy to reduce corruption levels (Bohara, Mitchell \& Mittendorf, 2004; Chowburry, 2004; Hill, 2003). Yet, related cross-country studies of some Latin American 
countries suggest that the transition to democracy did not help to reduce corruption as postulated by earlier theories. A classic example is that of Mexico, which adopted democracy but was plagued by a series of corruption scandals. There have also been countless cases of corruption in the European context (European Commission [EC], 2014). For instance, the Berlin anticorruption watchdog has consistently scored Italy high on the corruption index despite the country being a democratic state that has embraced the procedural aspects of democracy over the last six decades.

In contemporary studies, an examination of the role of educational attainment has produced mixed results. However, the normative connection has it that education enhances awareness of the devastating effects of corruption on well-being; hence the relation is negative. Whereas proponents in related studies are of the view that higher educational attainment encourages participation in corrupt activities in some respects (see Kaffenberger, 2012; Mocan, 2008; Truex, 2011), others have argued that, when there are sound policies in place, educational attainment can be indirectly useful in the fight against corruption (see Asongu, 2015; Cheung \& Chan, 2008).

\subsubsection{Institutional causes}

The institutional perspective basically focuses on set of rules that shape human behaviour and interaction. This strand allows for the use of other subjective measures used to gauge the effectiveness of anticorruption policies. The perspective acknowledges that corruption flourishes in structures that are dysfunctional. It also exposes the ineptitude among government agencies in respect of governance.

In terms of the institutional perspective, we consider press freedom or the media as a whistleblowing institution. The theory asserts that the fundamental role of the press is to act as a check on those who should represent the public interest. The hypothesis further asserts that corruption scandals freely investigated and exposed by the mass media act as a deterrent to bureaucrats and politicians seeking to engage in corrupt practices (Brunnetti \& Guzman, 2003; Camaj, 2013; Dahlström, 2010; Färdigh, 2012; Pellegrini, 2011).

The absence of rule of law has been identified as a determinant of corruption under the institutional dichotomy. In the words of the Executive Director of the United Nations Office on Drugs and Crime (UNODC), "where corruption exists, the rule of law cannot flourish". This implies that the rule of law and corruption are inversely related (Fedotov, 2012). Corruption and bribery circumvent fair tender processes, and the consequences are severe: funding intended for life-enhancing projects (such as schools and hospitals) may be diverted into the hands of corrupt individuals. Corruption undermines the rule of law by eroding democratic institutions that are essential for fair and equitable societies. Thus, only when the rule of law prevails can sustainable development be guaranteed. Although in theory this appears to be true, there is relatively little empirical support for this claim.

According to some authors, economic freedom as a measure has proved beneficial in reducing corruption. However, it has been documented that a lack of policies on competition and an absence of government regulation may give rise to greater corruption. This has been proven empirically in related studies, with economic freedom and regulatory quality being shown to have a negative relationship with regard to corruption. However, this ultimately depends on the distinctive character of the development path of the country in question (Graeff \& Mehlkop, 2003; Kumar, 2011; Pieroni \& D’Agostino, 2013).

Subordinate to the components of economic institutions identified as determinants of corruption and gaining popularity in contemporary literature of late, but subjectively viewed as mere conjecture, is the aspect of protecting secured property rights. According to Dong and Torgler (2011), democracy works better when the system of secured property rights is effective. Related to this assertion is the belief that the absence of a system of property rights leads to an increase in corruption.

In the view of other researchers, absence of accountability, especially when it is lacking on the part of politicians and bureaucrats, creates opportunities for corruption to thrive. For instance, Brinkerhoff (2004) explicates three key elements of accountability (i.e.: goals measurement and 
result; justification of results; and punishment/sanctions) that lead either to the proliferation or curtailment of corruption. Accountability is the obligation of government to demonstrate effectiveness in achieving goals and meeting the demands of the public (Segal \& Summers, 2002). Empirically, this has not been adequately researched, as accountability is more of a qualitative variable. However, in recent times, there have been an increasing number of attempts to measure the effectiveness of governance structures from one country to another by the World Bank using the World Governance Indicators (WGI). The indicators variously measure governance in relation to policy effectiveness, control of corruption, and accountability, among a host of other factors. Schumacher (2013), for instance, points out that improvements in electoral accountability lead to a decrease in bribery while increasing trust. However, this has not been empirically proven.

Based on the theoretical and empirical evidence from the literature, the sources of corruption are varied and can thus be broadly categorised on the basis of three main perspectives. These perspectives are further identified under the cost-benefit incentive strands. To establish a solid foundation for the empirical analysis, we provide a summary of the sources with the corresponding signs suggested by the literature (see Table 1).

Table 1

Sources of corruption

\begin{tabular}{|c|c|c|c|c|}
\hline \multicolumn{2}{|c|}{ Cost } & \multicolumn{3}{|c|}{ Benefits } \\
\hline Sources of corruption & \multirow{2}{*}{ Sign } & Sources of corruption & \multirow{2}{*}{ Sign } & Sources of corruption \\
\cline { 1 - 3 } Institutional causes & & Contemporary causes & Historical roots \\
\hline Press freedom & - & Aid inflows & + & Bureaucratic cost \\
Government effectiveness & - & Wages of bureaucrats & - & Ethnic fractionalisation \\
Regulatory quality & + & Resource abundance & British colony \\
Rule of law & - & Trade freedom & + & - \\
Property rights protection & - & Trade openness & - & \\
Size of government & + & Contemporary democracy & - & \\
& & Education & + & \\
\hline
\end{tabular}

Source: Authors' construct

\section{Empirical analysis}

\subsection{Data and methodology}

We explore the causes of corruption in respect of 22 countries in sub-Saharan Africa, with updated data from various sources for the period 1996 to 2013. The dependent variable is the index of perceived level of corruption of Transparency International. We also control for other variables such as population growth and economic prosperity using gross domestic product (GDP) growth rates in the full specification. It should be noted that, because corruption is a cultural issue, the variables used are lagged to account for lag effect and persistence. The resulting descriptive statistics and countries are presented in Table 2 with variable definitions and corresponding sources.

Our baseline specification for investigating the causes of corruption is similar to that of Pellegrini (2011) and Dong and Torgler (2013) and is of the form:

$$
Y_{\text {cor }, i t}=a_{0}+\beta_{1} \sum_{i=1}^{3} \text { Hist }_{i t}+\beta_{2} \sum_{i=2}^{6} \text { Contem }_{i t}+\beta_{3} \sum_{i=3}^{6} \text { instit }_{i t}+\beta_{j} \sum_{j}^{2} \text { Cont }_{i t}+\mu_{i}+\gamma_{t}+\varepsilon_{i t}
$$

Owing to variations and to ensure comparability, this specification measures the wage level of bureaucrats using the natural logarithm of per capita income as proxy for the countries involved. Education is the proportion of primary and secondary enrolments. We used a dummy variable to represent British colonial heritage. The three error terms in the specification account for regional fixed effects such as culture that are unobserved but strongly affect corruption. 
Table 2

Data description and presentation of countries

\begin{tabular}{|c|c|c|c|c|c|}
\hline Variables & Years & Description & Mean & Std. Dev. & Source \\
\hline \multicolumn{6}{|c|}{ PANEL A: Summary statistics } \\
\hline Economic prosperity & $1970-2013$ & $\begin{array}{l}\text { A proxy of annual percentage growth rate of GDP per } \\
\text { capita based on constant local currency. }\end{array}$ & 1.169 & 6.666 & World Bank \\
\hline Primary ENR & $1970-2013$ & Total enrolment in primary education, regardless of age. & 82.92 & 27.93 & World Bank \\
\hline Secondary ENR & $1970-2013$ & Total enrolment in secondary education, regardless of age. & 26.47 & 20.97 & World Bank \\
\hline Population growth & $1970-2013$ & $\begin{array}{l}\text { Exponential rate of growth of mid-year population from year } \\
t-1 \text { to } t \text {. }\end{array}$ & 2.701 & 0.879 & World Bank \\
\hline $\begin{array}{l}\text { Resource } \\
\text { abundance }\end{array}$ & $1970-2013$ & $\begin{array}{l}\text { Sum of all rents (from natural gas, coal (hard and soft), } \\
\text { minerals, and forests). }\end{array}$ & 11.89 & 13.53 & World Bank \\
\hline $\log$ (Aid inflows) & $1970-2013$ & $\begin{array}{l}\text { Logarithm of aid inflow is the transfer of capital for the } \\
\text { benefit of the recipient country or its population. }\end{array}$ & 8.147 & 0.742 & World Bank \\
\hline $\begin{array}{l}\text { log (Bureaucrats' } \\
\text { wages) }\end{array}$ & $1970-2013$ & $\begin{array}{l}\text { A proxy of per capita income used to represent the average } \\
\text { government wage as a multiple of GDP per capita. }\end{array}$ & 2.802 & 0.393 & World Bank \\
\hline Trade openness & $1970-2013$ & $\begin{array}{l}\text { A measure of the openness of the economy and equals the } \\
\text { share of imports over GDP. }\end{array}$ & 67.72 & 27.73 & World Bank \\
\hline Corruption index & $1996-2013$ & $\begin{array}{l}\text { Perceived level of corruption. Countries ranked on a scale } \\
\text { of } 100 \text { ("very clean") to } 0 \text { (highly corrupt). }\end{array}$ & 2.845 & 1.016 & $\begin{array}{l}\text { Transparency } \\
\text { International }\end{array}$ \\
\hline Press freedom & $1996-2013$ & $\begin{array}{l}\text { The degree to which the country permits the free flow of } \\
\text { news and information. Scored from } 0 \text { (best) to } 100 \text { (worst). }\end{array}$ & 51.4 & 16.45 & $\begin{array}{l}\text { Freedom } \\
\text { House }\end{array}$ \\
\hline $\begin{array}{l}\text { Contemporary } \\
\text { democracy }\end{array}$ & $1970-2012$ & $\begin{array}{l}\text { Index of democracy based on five key institutional } \\
\text { characteristics. } 0=\text { most autocratic to } 10=\text { most } \\
\text { democratic. }\end{array}$ & -1.907 & 19.49 & $\begin{array}{l}\text { Polity IV } \\
\text { Project }\end{array}$ \\
\hline $\begin{array}{l}\text { Government } \\
\text { effectiveness }\end{array}$ & $1996-2013$ & $\begin{array}{l}\text { The quality of public services and the civil service, and the } \\
\text { degree of independence from political pressures; ranges } \\
\text { from }-2.5 \text { to } 2.5 \text {, with higher values = better governance } \\
\text { outcomes. }\end{array}$ & -0.638 & 0.585 & WGI/WB \\
\hline Size of government & $1998-2013$ & $\begin{array}{l}\text { The four components that indicate the extent to which } \\
\text { countries rely on the political process to allocate resources } \\
\text { as well as goods and services. }\end{array}$ & 6.218 & 1.063 & $\begin{array}{l}\text { Economic } \\
\text { Freedom of } \\
\text { the World } \\
\text { Project (EFW) }\end{array}$ \\
\hline Regulatory quality & $1996-2013$ & $\begin{array}{l}\text { Perception of the ability of the government to formulate and } \\
\text { implement sound policies; ranging from }-2.5 \text { to } 2.5 \text {. }\end{array}$ & -0.502 & 0.584 & $W G I / W B$ \\
\hline Rule of law & $1996-2013$ & $\begin{array}{l}\text { Extent to which agents have confidence in, and abide by, } \\
\text { rules. }\end{array}$ & -0.419 & 0.523 & WGI/WB \\
\hline $\begin{array}{l}\text { Property rights } \\
\text { protection }\end{array}$ & $1998-2013$ & $\begin{array}{l}\text { Degree to which a country's laws protect private property } \\
\text { rights, as well as the extent of law enforcement by } \\
\text { government. }\end{array}$ & 42.66 & 13.34 & HF/Polity IV \\
\hline Bureaucratic cost & $1996-2013$ & $\begin{array}{l}\text { Subcomponent based on the Global Competitiveness } \\
\text { Report relating to the question: Standards regarding } \\
\text { product/service quality, energy and other regulations } \\
\text { (outside environmental regulations) in your country are: (1= } \\
\text { Lax or non-existent, } 7=\text { among the world's most stringent). }\end{array}$ & 5.225 & 0.819 & $\begin{array}{l}\text { Economic } \\
\text { Freedom of } \\
\text { the World } \\
\text { Project (EFW) }\end{array}$ \\
\hline Economic freedom & $1998-2013$ & $\begin{array}{l}\text { Degree to which the policies and institutions of countries } \\
\text { are supportive of economic freedom. The scores range } \\
\text { from } 0 \text { to } 10 .\end{array}$ & 57.76 & 5.074 & $G L H$ \\
\hline British colony & $1970-2013$ & $\begin{array}{l}\text { Dummy variable for countries that have been under British } \\
\text { control. }\end{array}$ & 0.29 & 0.45 & $W F$ \\
\hline $\begin{array}{l}\text { Ethnic } \\
\text { fractionalisation }\end{array}$ & $1961 / 1985 / 1995$ & $\begin{array}{l}\text { The probability that two randomly selected individuals in the } \\
\text { population belong to different groups. }\end{array}$ & 0.758 & 0.125 & $\begin{array}{l}\text { Roede \& } \\
\text { Alesina et al. }\end{array}$ \\
\hline & & $\begin{array}{l}\text { Mozambique, Liberia, Senegal, Togo } \\
\text { anzania, Zambia, Malawi, Burkina Faso, Botswana, Côte d'Ivoire, N }\end{array}$ & amibia & & \\
\hline
\end{tabular}

Source: Authors' construct

To determine the sources of corruption in sub-Saharan Africa, it is important for the study to address the problems of multicollinearity (see the correlation matrix in Table A1 in the Appendix) and endogeneity. To reduce the issue of multicollinearity, we intuitively segregate the variables that are highly correlated. In this way, we are able to control the condition numbers and variance inflation factors in the panel regressions to be lower than 100 and 10, respectively. We also follow other research approaches (see Dong \& Torgler, 2013; Hair, Anderson, Tatham \& Black, 1995) and assume that there is no serious collinearity in the regressions. To deal with the issue of endogeneity, the study depends on three estimation strategies. We rationalise our decision on the 
basis of the fact that corruption is an institutional problem that lasts for a long time. Moreover, since the major source of bias in our panel regressions may be both time-variant and invariant historical factors, we decided to interchangeably use a combination of the conventional fixed effect and pooled OLS (POLS), while controlling for unobserved country fixed effects that influence corruption. What should be noted is that an attempt is made to have the variables lagged for one year to account for persistence. However, the fixed-effects regression may not necessarily be a viable approach in identifying the causal effects of corruption and its sources when omitted time-variant historical factors are considered. To address this concern, we develop a unified framework to investigate the sources of corruption using the POLS approach. This approach allows the countries within the sample to be observed as one entity.

The results from the POLS and fixed effect are further bolstered with the instrumental-variable (IV) approach to identify the sources of corruption. This is set against the shortcomings identified with the fixed-effect approach. Thus the IV approach is used whenever necessary. We strongly believe that, through these approaches, we will be able to deal with the problem related to endogeneity in determining the sources of corruption.

We investigate the sources of corruption using our baseline regression in Equation (1) and then compare the results with those of other related studies in the literature. It should be pointed out that the estimation strategy follows the theoretical classifications discussed in the literature under the three broad sources identified. We test the robustness of each thematic area against the variables highlighted by the theory. We also do further tests for robustness with estimates that jointly use full specification. In all the processes, we make sure that multicollinearity is dealt with by controlling the conditional variance.

\subsection{Findings and discussion}

\subsubsection{POLS estimates}

To empirically test the effects of anticorruption policies on corruption, we examine the impact of the media (press freedom) as an institution, government effectiveness, regulatory quality, the rule of law, economic institution (property rights protection) and size of government on corruption. The results for the POLS estimates are presented in Table 3.

Regression (1) investigates variables grouped under the institutional dichotomy. The explanatory variables of press freedom and regulatory quality are indeed validated, as both are seen to be statistically significant $(p<0.001)$ with the expected negative coefficients. This suggests that the media as an institution is less associated with corruption. To forecast the impact of press freedom on corruption would imply that a 1 per cent change in the value of press freedom is associated with a 0.0194 point reduction in corruption levels in sub-Saharan Africa.

However, the negative relation with regard to regulatory quality should be interpreted carefully based on how the variable has been defined. On this basis, it presupposes that regulatory quality is positively associated with corruption. This means that the quality of regulation creates seepages that allow the practice to thrive in the region. In terms of elasticity, a 1 per cent change in regulatory quality worsens governance, which substantially raises the level of corruption in the region by almost 1.044 points. However, in terms of the argument in contemporary literature that the size of government is a determinant of corruption, the study finds this variable to be insignificant but positive. Regression (1) cross-variable variance is high (83 per cent), which implies that the goodness of fit in the choice of variables selected as sources of corruption under the institutional variants in sub-Saharan Africa is largely theoretically sound.

To determine whether historical background has a lasting impact on the spate of corrupt practices, we empirically test for the validity of this notion using bureaucratic cost, British heritage, and ethnic-linguistic fractionalisation. We find ethnic-linguistic fractionalisation to be negative in Regression (2). Ethnicity in this regard is less associated with corruption in the region. Although the influence is seen to be minimal, it does not, however, negate the fact that fractionalisation is a medium through which corruption permeates. 
Table 3

Corruption and its sources in sub-Saharan Africa: POLS estimation

\begin{tabular}{|c|c|c|c|c|}
\hline & (1) & (2) & (3) & (4) \\
\hline Variables & Corruption & Corruption & Corruption & Corruption \\
\hline \multicolumn{5}{|l|}{ Contemporary causes } \\
\hline \multirow[t]{2}{*}{$\log (a i d)$} & & & 0.041 & 0.291 \\
\hline & & & $(0.029)$ & $(0.212)$ \\
\hline \multirow[t]{2}{*}{ Log (wages of bureaucrats) } & & & $0.361^{* \star *}$ & $1.940 *$ \\
\hline & & & $(0.101)$ & $(1.118)$ \\
\hline \multirow[t]{2}{*}{ Natural resources } & & & $-0.003^{*}$ & -0.008 \\
\hline & & & $(0.001)$ & $(0.017)$ \\
\hline \multirow[t]{2}{*}{ Trade freedom } & & & 0.007 & -0.112 \\
\hline & & & $(0.013)$ & $(0.078)$ \\
\hline \multirow[t]{2}{*}{ Contemporary democracy } & & & -0.000 & -0.002 \\
\hline & & & $(0.000)$ & $(0.003)$ \\
\hline \multirow[t]{2}{*}{ Education } & & & $-0.002^{*}$ & $-0.032^{* *}$ \\
\hline & & & $(0.001)$ & $(0.014)$ \\
\hline \multicolumn{5}{|l|}{ Institutional factors } \\
\hline \multirow[t]{2}{*}{ Press freedom } & $-0.019^{* * *}$ & & & $-0.042^{* *}$ \\
\hline & $(0.003)$ & & & $(0.019)$ \\
\hline \multirow[t]{2}{*}{ Regulatory quality } & $-1.044^{* * *}$ & & & 0.298 \\
\hline & $(0.096)$ & & & $(0.607)$ \\
\hline \multirow[t]{2}{*}{ Rule of law } & -0.029 & & & 0.252 \\
\hline & $(0.076)$ & & & $(0.294)$ \\
\hline \multirow[t]{2}{*}{ Property rights } & 0.003 & & & 0.008 \\
\hline & $(0.003)$ & & & $(0.007)$ \\
\hline \multirow[t]{2}{*}{ Size of government } & 0.025 & & & -0.079 \\
\hline & $(0.025)$ & & & $(0.048)$ \\
\hline \multicolumn{5}{|l|}{ Historical roots } \\
\hline \multirow[t]{2}{*}{ Bureaucratic cost } & & -0.118 & & 0.002 \\
\hline & & $(0.081)$ & & $(0.072)$ \\
\hline \multirow[t]{2}{*}{ Ethnic fractionalisation } & & $-4.056^{\star * *}$ & & $-4.603^{*}$ \\
\hline & & $(0.445)$ & & $(2.408)$ \\
\hline \multirow[t]{2}{*}{ Economic prosperity } & & & & -0.003 \\
\hline & & & & $(0.011)$ \\
\hline \multirow[t]{2}{*}{ Population growth } & & & & 0.007 \\
\hline & & & & $(0.123)$ \\
\hline \multirow[t]{2}{*}{ Constant } & $3.830^{* * *}$ & $6.483^{\star * *}$ & $1.265^{\star * *}$ & 2.378 \\
\hline & $(0.201)$ & $(0.573)$ & $(0.347)$ & $(4.428)$ \\
\hline Year dummy & Yes & Yes & Yes & Yes \\
\hline Country dummy & No & No & No & No \\
\hline Observations & 125 & 245 & 788 & 52 \\
\hline $\mathrm{R}^{2}$ & 0.827 & 0.269 & 0.955 & 0.870 \\
\hline F-statistics & 99.84 & 30.95 & 248.6 & 22.41 \\
\hline
\end{tabular}

Note: Robust standard errors in parentheses; " $p<0.10,{ }^{* *} p<0.05,{ }^{* * *} p<0.01$.

Note that the adoption of democracy calls for increased stakeholder participation, accountability and transparency, and that this has had a mitigating effect on cronyism, favouritism and nepotism. Therefore, the correlation in Table 3 does not support the explanation given in the literature which suggests that the greater the ethnic diversity of a society, the more bureaucrats and politicians abuse their positions in order to favour members of their own ethnic class. The dominant cultural trait in sub-Saharan Africa used to be collectivism, which, by extension, increases susceptibility to becoming parochial and promoting cronyism. Nevertheless, the effect of globalisation has gradually diluted this through the adoption of Western lifestyles. Democracy engenders 
competition, which means that there may be less favouritism. In general, some of the findings relating to historical roots support other studies in the literature (Glaeser \& Shleifer, 2002; Glaeser, La Porta, Lopez-de-Silanes \& Shleifer, 2004; Mauro, 1995; Treisman, 2000, 2007).

With regard to the contemporary causes, it can be seen that the wage level of bureaucrats, resource abundance and education are variedly associated with corruption in Africa. The negative coefficient in respect of resource abundance can be explained on the basis that natural endowments have no direct effect on corruption, but indirectly affect corruption through rent-seeking and patronage. On a continuum, rent indirectly promotes activities geared towards influencing policymakers who have power in the distribution of exploitation rights, thus drawing away resources from other productive activities. However, arguments advanced by researchers such as Ohler et al. (2012) and others based on the fuzzy correlation between aid and development are not supported by the present research. Although contemporary democracy is insignificant as a factor, it has the expected negative coefficient to support the popular proposition that democracy is less associated with corruption. Regarding bureaucrats' wage levels, the study finds a positive relationship between such wages and corruption. This implies that the current income levels explain why corruption continues to flourish in the region. Resource abundance and education (secondary enrolment), on the other hand, are markedly less associated with corruption. The proliferation of media houses means that awareness of corruption is enhanced. This awareness increases participation at the grassroots level in the fight against corruption. It explains why educational attainment is less associated with corruption in Africa. The evidence supports the indirect role of education in the fight against corruption on the continent (Asongu, 2015; Cheung \& Chan, 2008; Truex, 2011).

Although some of the variables are insignificant in the regression, it is nevertheless necessary to comment briefly on them in view of the signs associated with them. In the first place, we find the impact of contemporary democracy to be less associated with corruption in the sub region when inferred from the negative coefficient it consistently has from the two estimators. This implies that the procedural aspect of democracy (free elections and electoral competition) in the subregion increases participation, which may probably act as a check on politicians (Bohara et al., 2004; Chowburry, 2004; Hill, 2003). Secondly, aid inflow bears a positive sign with regard to corruption in sub-Saharan Africa. This is possibly because conditionalities with regard to aid are used as a medium either to transfer funds back to donors or to "grease palms" in return for special favours; hence this eliminates the incentive to fight corruption (Forson et al., 2015; Ohler et al., 2012).

Evidence from the full specification in Regression (4) confirms the previous results. However, economic prosperity and population growth used as controls are found to be insignificant. Nevertheless, the negative relation in respect of economic prosperity has some important implications which warrant attention. It suggests that economic prosperity is less associated with corruption. This means that, as countries in the subregion progress economically, their ability to formulate and undertake qualitative institutional reforms designed to tackle societal challenges may be enhanced. This is theoretically supported and can also be explained within the marginalutility-of-income hypothesis (Asongu, 2013; Dong \& Torgler, 2013; Schulze \& Frank, 2003).

\subsubsection{Fixed-effect estimates}

In Table 4, we consider the impact of the explanatory variables that are time-invariant in Regression (1). We find a contrasting relation, as press freedom is positively significant, suggesting that it is associated with corruption on the continent. The media as a whistle-blowing institution is supposed to serve as a check on corrupt politicians and bureaucrats. It should freely investigate and place in the public domain corrupt bureaucrats and politicians. Yet, in Africa, owing to political patronage, the media has increasingly reneged on its duty as a whistle-blowing institution; hence the variation in the relation. For example, there are media outlets that operate by defending politicians and political parties. Facts pertaining to corrupt leaders are distorted in the process. The negative relationship in respect of government effectiveness warrants some attention given how the variable is measured. The negative relation attests to anticorruption agencies in the subregion being under constant political pressure. Such a situation could lead to circumvention. 
This means that governance structures have done little in the fight against corruption owing to interference. In terms of elasticity, a 1 per cent decrease in government effectiveness worsens governance in the subregion, which increases the level of corruption by 0.48 points.

As far as historical roots are concerned, the results in Regression (2) reveal that none of the variants considered is significant. A possible reason could be the range of controls used to capture time and country effects. Again, the variables considered, especially ethnicity are fundamentally a cultural element, which means time has a limited effect on them. The results here contrast with the POLS outcomes. The model is, however, jointly insignificant at the 1 per cent level of significance.

Table 4

Corruption and its sources in sub-Saharan Africa: Fixed-effect estimation

\begin{tabular}{|c|c|c|c|c|}
\hline & (1) & (2) & (3) & (4) \\
\hline Variables & Corruption & Corruption & Corruption & Corruption \\
\hline \multicolumn{5}{|l|}{ Institutional factors } \\
\hline \multirow[t]{2}{*}{ Press freedom } & $0.069^{* * *}$ & & & 0.027 \\
\hline & $(0.024)$ & & & $(0.075)$ \\
\hline \multirow[t]{2}{*}{ Government effectiveness } & $-0.480^{*}$ & & & 0.111 \\
\hline & $(0.460)$ & & & $(0.282)$ \\
\hline \multirow[t]{2}{*}{ Rule of law } & 0.048 & & & 0.154 \\
\hline & $(0.072)$ & & & $(0.291)$ \\
\hline \multirow[t]{2}{*}{ Property protection } & -0.000 & & & 0.009 \\
\hline & $(0.003)$ & & & $(0.007)$ \\
\hline \multirow[t]{2}{*}{ Size of government } & 0.026 & & & -0.079 \\
\hline & $(0.025)$ & & & $(0.048)$ \\
\hline \multicolumn{5}{|l|}{ Historical roots } \\
\hline \multirow[t]{2}{*}{ Bureaucratic cost } & & 0.021 & & 0.026 \\
\hline & & $(0.057)$ & & $(0.074)$ \\
\hline \multirow[t]{2}{*}{ Ethnic fractionalisation } & & -0.553 & & $-4.976^{*}$ \\
\hline & & $(0.766)$ & & $(2.364)$ \\
\hline \multicolumn{5}{|l|}{ Contemporary causes } \\
\hline \multirow[t]{2}{*}{$\log ($ aid) } & & & 0.041 & 0.355 \\
\hline & & & $(0.029)$ & $(0.221)$ \\
\hline \multirow[t]{2}{*}{ Log (income of bureaucrats) } & & & $0.361^{\star \star *}$ & $2.025^{\star}$ \\
\hline & & & $(0.101)$ & $(0.011)$ \\
\hline \multirow[t]{2}{*}{ Resource abundance } & & & $-0.003^{*}$ & -0.005 \\
\hline & & & $(0.001)$ & $(0.015)$ \\
\hline \multirow[t]{2}{*}{ Trade openness } & & & -0.000 & -0.121 \\
\hline & & & $(0.001)$ & $(0.082)$ \\
\hline \multirow[t]{2}{*}{ Contemporary democracy } & & & -0.000 & -0.002 \\
\hline & & & $(0.000)$ & $(0.003)$ \\
\hline \multirow[t]{2}{*}{ Education } & & & $-0.002^{*}$ & $-0.037^{* *}$ \\
\hline & & & $(0.001)$ & $(0.015)$ \\
\hline \multirow[t]{2}{*}{ Economic prosperity } & & & & -0.001 \\
\hline & & & & $(0.011)$ \\
\hline \multirow[t]{2}{*}{ Population growth } & & & & 0.001 \\
\hline & & & & $(0.124)$ \\
\hline \multirow[t]{2}{*}{ Constant } & -0.800 & $3.268^{* * *}$ & $1.604^{* * *}$ & -1.846 \\
\hline & $(1.431)$ & $(0.873)$ & $(0.357)$ & $(5.085)$ \\
\hline Year dummy & Yes & Yes & Yes & Yes \\
\hline Country dummy & Yes & Yes & Yes & Yes \\
\hline Observations & 125 & 245 & 788 & 62 \\
\hline $\mathrm{R}^{2}$ & 0.709 & 0.149 & 0.291 & 0.294 \\
\hline F-statistics & 17.47 & 1.328 & 2.445 & 1.98 \\
\hline
\end{tabular}

Note: Robust standard errors in parentheses; " $p<0.10,{ }^{* *} p<0.05,{ }^{* * *} p<0.01$. 
The fixed-effect estimates in Regression (3) in Table 4 corroborate the POLS results on the contemporary causes. Bureaucrats' wages, resource abundance, and education are collectively significant amidst the different signs. The model's explanatory power is low (adj. $\mathrm{R}^{2}=29 \%$ ), but the model is jointly significant at 1 per cent $(\mathrm{F}=2.45)$.

The two estimation strategies in Table 3 and 4 have consistently shown that income used as proxy for bureaucrats' wages substantially affects corruption in the subregion. However, Treisman (2000) and Glaeser and Saks (2006) suggest that such a relation might be suffering from potentially omitted variable bias and reverse causality between corruption and income (endogeneity). Indeed, the Hausman test of endogeneity in Table 5 confirms this. To address this, we need to find an instrumental variable that captures the wage characteristics of the countries in the sample within the subregion. Although the literature suggests colonial legacy and ethniclinguistic fractionalisation, we resorted to the intuitive criteria in order to find an instrument.

Table 5

Fixed-effect 2SLS (within) IV regression

\begin{tabular}{|c|c|c|c|c|c|}
\hline First-stage regression & (1) & (2) & (3) & (4) & (5) \\
\hline & \multicolumn{5}{|c|}{ Coefficients of corresponding instrumental variables in first-stage regressions } \\
\hline \multicolumn{6}{|l|}{ Variable instrumented } \\
\hline \multirow[t]{2}{*}{ Bureaucrats' wages } & $2.867^{\star * *}$ & $2.838^{* * *}$ & $4.218^{* * *}$ & $4.323^{\star * *}$ & $3.534^{* * *}$ \\
\hline & $(0.582)$ & $(0.575)$ & $(1.439)$ & $(1.518)$ & $(0.853)$ \\
\hline \multicolumn{6}{|l|}{ Instruments } \\
\hline \multirow[t]{2}{*}{ Press freedom } & 0.008 & 0.011 & 0.001 & 0.001 & 0.045 \\
\hline & $(0.025)$ & $(0.024)$ & $(0.006)$ & $(0.006)$ & $(0.028)$ \\
\hline \multirow[t]{2}{*}{ Resource abundance } & $-0.031^{\star *}$ & $-0.027^{\star \star}$ & $-0.003^{* *}$ & $-0.003^{*}$ & $-0.044^{* \star *}$ \\
\hline & $(0.009)$ & 0.009 & $(0.002)$ & $(0.003)$ & $(0.014)$ \\
\hline \multirow[t]{2}{*}{ Rule of law } & 0.0471 & $(0.120)$ & & & 0.084 \\
\hline & $(0.079)$ & 0.094 & & & $(0.089)$ \\
\hline \multirow[t]{2}{*}{ Property rights } & 0.004 & 0.003 & & & 0.004 \\
\hline & $(0.003)$ & $(0.003)$ & & & $(0.003)$ \\
\hline \multirow[t]{2}{*}{ Population growth } & $-0.146^{*}$ & $-0.134^{*}$ & & & $-0.161^{\star *}$ \\
\hline & $(0.051)$ & $(0.050)$ & & & $(0.060)$ \\
\hline \multirow[t]{2}{*}{ Aid inflows } & & 0.133 & & & $0.307^{*}$ \\
\hline & & $(0.095)$ & & & $(0.136)$ \\
\hline \multirow[t]{2}{*}{ Contemporary democracy } & & & & -0.001 & -0.001 \\
\hline & & & & $(0.0012)$ & $(0.002)$ \\
\hline \multirow[t]{2}{*}{ Openness } & & & & & -0.016 \\
\hline & & & & & $(0.036)$ \\
\hline \multirow[t]{2}{*}{ Education } & & & & & $-0.014^{\star *}$ \\
\hline & & & & & $(0.006)$ \\
\hline \multirow[t]{2}{*}{ Economic prosperity } & & & & & -0.003 \\
\hline & & & & & $(0.005)$ \\
\hline \multirow[t]{2}{*}{ Constant } & -5.328 & -6.384 & -8.654 & -8.923 & -10.504 \\
\hline & $(1.964)$ & $(2.140)$ & $(3.985)$ & $(4.198)$ & $(3.546)$ \\
\hline Year dummy & Yes & Yes & Yes & Yes & Yes \\
\hline \multirow[t]{2}{*}{ Hausman test } & 15.73 & & & & 2.59 \\
\hline & {$[0.68]$} & & & & {$[0.98]$} \\
\hline Anderson canon & 19.10 & 9.03 & 18.11 & 17.02 & 10.75 \\
\hline Corr. LM statistic & {$[0.00]$} & {$[0.00]$} & {$[0.00]$} & {$[0.00]$} & {$[0.00]$} \\
\hline Number of observations & 140 & 140 & 679 & 670 & 140 \\
\hline
\end{tabular}


This is against the backdrop that the mechanism to establish a relation, as suggested by the literature, in the presence of time-invariant institutional factors and time-variant factors may be difficult. Nevertheless, as set out in the objectives of the present paper, our prime focus is to assess the impact of institutional effectiveness in combating corruption in sub-Saharan Africa. In this regard, we instrumented with the variable wages and treated government effectiveness as the endogenous variable in the fixed effect within the IV regression. The results are similar to previous ones, even when we instrument wages to capture the country characteristics (see Table 5).

\section{Conclusion and policy recommendations}

This paper explored and assessed the causes of corruption in sub-Saharan Africa through the lenses of three broad sources (historical roots, contemporary causes, and institutional causes). The crux of the paper is the attempt to assess the effectiveness of anticorruption policies in combating the level of corruption in the subregion by incorporating institutional factors. This approach allows countries in the subregion to be assessed on the basis of the same institutional characteristics while focusing on an avalanche of subjective and objective factors. Our study complements other crosscountry studies on the causes of corruption by presenting contextual evidence on sub-Saharan Africa. The number of independent variables and the approach used allowed the paper to deal with omitted variable bias and endogeneity. A mixture of time-variant and time-invariant variables also permitted the study to assess the impact of fixed effect on the causes of corruption in the subregion.

From the empirical analysis, we find ethnic diversity, resource abundance and educational attainment to be less associated with corruption, whereas wage levels of bureaucrats and anticorruption controls using government effectiveness and regulatory quality breed substantial corruption. These findings are variedly supported in the literature. For instance, as opposed to the known notion (see Vian, 2008; Mauro, 1995), ethnic diversity in the region is increasingly becoming less associated with corruption. In our view, the adoption of democracy, which calls for increased stakeholder participation, accountability and transparency, has had a mitigating effect on cronyism and nepotism. Democracy breeds competition, which subdues anything of the nature of favouritism. On a continuum, we find educational attainment to be less associated with corruption, which thus supports the argument in the literature on the indirect effect of education in the fight against corruption (Asongu, 2015; Cheung \& Chan, 2008). Yet, the wage level of bureaucrats and government machinery which underscores the quality of existing institutions mandated to set rules to guide human behaviour lend credence to the theories in the literature (Dong \& Torgler, 2013; Asongu, 2013; Schulze \& Frank, 2003). In addition, we find the effect of the media as an institution to be inconclusive, as, at one point, it is seen to be less associated with corruption (see Brunnetti \& Guzman, 2003; Camaj, 2013; Dahlström, 2010; Färdigh, 2012; Pellegrini, 2011) whereas at another it contributes to the menace. We elucidate on the latter by arguing that owing to political patronage, some of the media houses have reneged on their core function and have often been used in distorting facts.

Our empirical findings have substantial policy implications. To begin with, the fight against corruption on the subcontinent needs to be reinvented through qualitative and assertive institutional reforms. The assertiveness of the institutions will reduce the level of impunity and thus help shape human behaviour in relation to the social canker of corruption. Efforts should also be made to enhance the conditions of service of both public and civil servants so as to dissuade them from being tempted to engage in the practice of corruption. Moreover, given that existing educational systems are seen to be less associated with corruption, using them as a conduit to intensify awareness of the devastating effect of corruption on national development will be more pragmatic in the fight against corruption. This approach progressively has a multiplier effect in the long run. Future research should endeavour to provide a microperspective focusing on countrylevel experience with regard to the effectiveness of corruption controls in order to bolster this regional analysis. 
One of the existential limitations of this study is the data challenges it encountered. As a result, we recommend future research to innovate and evolve proxies or measurements for variables such as wages of bureaucrats and experience of corruption, to mention but a few. This could be done either at the microlevel or macrolevel to bring to the fore country-level or regional experience within the African continent.

\section{Endnote}

1 Address of the corresponding author: Graduate School of Public Administration, National Institute of Development Administration (NIDA), 118 M003, Seri Thai Road, Klong Chan, Bangkapi, Bangkok 10240 Thailand. Tel.: +66-840-724-426; email: datoeagle@yahoo.com.

\section{Acknowledgements}

The lead author wishes to thank Prof. Ponlapat Buracom (of the National Institute of Development Administration, Thailand) who was his supervisor for his doctoral dissertation. His insightful comments, direction and encouragement proved vital in the successful completion of the lead author's doctoral research. The present paper is a section of the empirical part of the said dissertation. Many thanks are also due to the anonymous referees and the editor for their invaluable comments. Any remaining errors are those of the authors.

\section{References}

ACEMOGLU, D. \& VERDIER, T. 2000. The choice between market failures and corruption. America Economic Review, 1(90):194-211.

AKURUT, C. 2013. Foreign aid and corruption: Their relationship and the Ugandan government's quandary. Consultancy Africa Intelligence. http://www.consultancyafrica.com/index.php?option=com content\&view=article\&id=1204:foreign-aid-and-corruption-their-relationship-and-the-ugandan-governmentsquandary-part-1-\&catid=60:conflict-terrorism-discussion-papers\&Itemid=265 [accessed March 2014].

ALESINA, A. \& DOLLAR, D. 2000. Who gives foreign aid to whom and why? Journal of Economic Growth, 5(1):33-63.

ASONGU, S.A. 2013. Fighting corruption in Africa : Do existing corruption-control levels matter? International Journal of Development Issues, 12(1):36-52.

ASONGU, S.A. 2015. The incremental effect of education on corruption: Evidence of synergy from lifelong learning. Economics Bulletin, 35(4):2288-2308.

BECKER, G.S. 1968. Crime and punishment - economic approach. Journal of Political Economy, 76(2): 169-217.

BILLGER, S.M. \& GOEL, R.K. 2009. Do existing corruption levels matter in controlling corruption? Crosscountry quantile regression estimates. Journal of Development Economics, 90:299-305.

BOHARA, A.K., MITCHELL, N.J. \& MITTENDORF, C.F. 2004. Compound democracy and the control of corruption: A cross-country investigation. Policy Studies Journal, 32(4):481-499.

BRINKERHOFF, D.W. 2004. Accountability and health systems: Toward conceptual clarity and policy relevance. Health Policy and Planning, 19(6):371-379.

BRUNNETTI, A. \& GUZMAN, E. 2003. A free press bad news for corruption. Journal of Public Economics, 32(4):481-499.

BURNSIDE, C. \& DOLLAR, D. 2000. Aid, policies, and growth. American Economic Review, 90(4):847868.

BURNSIDE, C. \& DOLLAR, D. 2004. Aid, policies, and growth: Revisiting the evidence. Washington. CAMAJ, L. 2013. The media's role in fighting corruption: Media effects on governmental accountability. International Journal of Press/Politics, 18(1):21-42.

CHAUFEN, A.A. \& GUZMAN, E. 1999. Economic freedom... . Pubished in G.P. O’Driscoll, K.R. Holmes \& M. Kirkpatrick (eds), 2000 index of economic freedom. Washington: Heritage Foundation.

CHEUNG, H.Y. \& CHAN, A.W.H. 2008. Corruption across countries: Impacts from education and cultural dimensions. Social Science Journal, 45:223-239. 
CHOWBURRY, S.K. 2004. The effect of democracy and press freedom on corruption: An empirical test. Economic Letters, 85(1):93-101.

COLLIER, P. \& DOLLAR, D. 2002. Aid allocation and poverty reduction. European Economic Review, 46(8):1475-1500.

COLLIER, P. \& DOLLAR, D. 2004. Development effectiveness: What have we learnt? The Economics Journal, 114(496):244-271.

DAHLSTRÖM, T. 2010. The role of the media in combating corruption. Jönköping. www.idec.gr/.../corruption conference/Tobias Dahlstro. [accessed April 2013].

DIMANT, E. 2014. The nature of corruption: An interdisciplinary perspective. Germany. http://groups.unipaderborn.de/fiwi/RePEc/pdf/wpaper/WP79.pdf [accessed June 2014].

DONG, B. \& TORGLER, B. 2011. Democracy, property rights, income equality, and corruption. Milan. http://papers.ssrn.com/sol3/papers.cfm?abstract_id=1756816 [accessed April 2013].

DONG, B. \& TORGLER, B. 2013. Causes of corruption: Evidence from China. China Economic Review, 26:152-169.

EUROPEAN COMMISSION. 2014. Report from the Commission to the Council and the European Parliament: EU anti-corruption report. Brussels. ec.europa.eu/dgs/home-

affairs/e.../corruption/.../acr_2014_en.pdf [accessed October 2014].

FÄRDIGH, M.A. 2012. Free media and quality of government: The role of media in promoting quality of government institutions in the European Union. Nice.

www.qog.pol.gu.se/digitalAssets/1385/1385069_2012_13_f--rdigh.pdf [accessed May 2015].

FEDOTOV, Y. 2012. Where corruption flourishes, development and the rule of law fail. UNODC Press Release. https://www.unodc.org/unodc/en/press/releases/2012/September/where-corruption-flourishesdevelopment-and-the-rule-of-law-fail-says-unodc-chief.html [accessed March 2014].

FEINBERG, G. 2009. The epidemic of petit corruption in contemporary Cambodia: Causes, consequences and solutions. Crime Prevention and Community Safety: An International Journal, 11(4):277-296.

FORSON, J.A. 2016. A "recursive framework" of corruption and development: Comparison between sustainable and economic outcomes. World Journal of Entrepreneurial, Management and Sustainable Development, 12(4):281-306.

FORSON, J.A., BURACOM, P., BAAH-ENNUMH, T.Y. \& CARSAMER, E. 2015. Corruption, EU aid inflows and economic growth in Ghana: Cointegration and causality analysis. Contemporary Economics, 9(3):299-318.

FORSON, J.A. \& OPOKU, R.A. 2014. Government's restructuring pay policy and job satisfaction: The case of teachers in the Ga West municipal assembly of Ghana. International Journal of Management, Knowledge and Learning, 3(1):79-99.

GLAESER, E.L., LA PORTA, R., LOPEZ-DE-SILANES, F. \& SHLEIFER, A. 2004. Do institutions cause growth? Journal of Economic Growth, 9(3):271-303.

GLAESER, E.L. \& SAKS, R.E. 2006. Corruption in America. Journal of Public Economics, 90(6-7): 1053-1072.

GLAESER, E.L. \& SHLEIFER, A. 2002. Legal origins. Quarterly Journal of Economics, 117(4):1193-1229. GRAEFF, P. \& MEHLKOP, G. 2003. The impact of economic freedom on corruption: Different patterns for rich and poor countries. European Journal of Political Economy, 19(3):605-620.

HAIR, J.F. Jr, ANDERSON, R.E., TATHAM, R.L. \& BLACK, W.C. 1995. Multivariate data analysis (3 $^{\text {rd }}$ ed.) New York: Macmillan.

HILL, K.Q. 2003. Democratization and corruption: Systematic evidence from the American states. American Politics Research, 31(6):613-631.

JAEN, M.H. \& PARAVISINI, D. 2002. Wages, capture, and penalities in Venezuela. In Diagnosis corruption: Fraud in Latin America's public hospitals. Washington DC: Inter-American Development Bank: 57-94.

JAIN, A.K. 2002. Corruption: A review. Journal of Economic Surveys, 15(1):71-121. http://darp.lse.ac.uk/PapersDB/Jain_(JES01).pdf [accessed May 2015]. 
KAFFENBERGER, M. 2012. The effect of educational attainment on corruption participation in Sub-Sahara Africa. Graduate School of Vanderbilt University. http://etd.library.vanderbilt.edu/available/etd-03222012205534/unrestricted/Kaffenberger.pdf [accessed April 2013].

KLITGAARD, R. 1988. Controlling corruption. Berkeley, CA: University of California Press.

KNACK, S. 2013. Aid and donor trust in recipient country systems. Journal of Development Economics, 101:316-329.

KOLSTAD, I. \& SØREIDE, T. 2009. Corruption in natural resource management: Implications for policy makers. Resources Policy, 34(4):214-226.

KOTERA, G., OKADA, K. \& SAMRETH, S. 2012. Government size, democracy, and corruption: An empirical investigation. Economic Modelling, 29(6):2340-2348.

KUMAR, A. 2011. Interplay between corruption and economic freedom. Delhi.

ccsinternship.files.wordpress.com/.../254_interplay-between-corruption-a.... [accessed July 2014].

LA PORTA, R., LOPEZ-DE-SILANES, F., SHLEIFER, A. \& VISHNY, R. 1999. The quality of government. Journal of Law, Economics \& Organisation, 15(1):222-279.

LEITE, C. \& WEIDMANN, J. 1999. Does mother nature corrupt? Natural resources, corruption, and economic growth.Washington DC. http://www.imf.org/external/pubs/cat/longres.aspx?sk=3126 [accessed July 2014].

MAURO, P. 1995. Corruption and growth. Quarterly Journal of Economics, 110(3):681-712.

MOCAN, N. 2008. What determines corruption? International evidence from microdata. Economic Inquiry, 46(4):493-510.

NORTH, D.C. 1990. Institutions, institutional change, and economic performances. New York: Cambridge University Press.

OHLER, H., NUNNENKAMP, P. \& DREHER, A. 2012. Does conditionality work? A test for an innovative US aid scheme. European Economic Review, 56:138-153.

PELLEGRINI, L. 2011. Causes of corruption: A survey of cross-country analysis and extended results. In Corruption, development and the environment. Berlin: Springer:29-49.

PIERONI, L. \& D'AGOSTINO, G. 2013. Corruption and the effects of economic freedom. European Journal of Political Economy, 29(1):54-72.

ROSE-ACKERMAN, S. 1999a. Corruption and government: Causes, consequences, and reform. Cambridge: Cambridge University Press.

ROSE-ACKERMAN, S. 1999b. Political corruption and democracy. Yale.

http://digitalcommons.law.yale.edu/fss_papers/592/ [accessed October 2014].

SCHOTTER, A. 1981. The economic theory of social institutions. New York: Cambridge University Press.

SCHULZE, G.G. \& FRANK, B. 2003. Deterrence versus intrinsic motivation: Experimental evidence on the determinants of corruptibility. Economics of Governance, 4(2):143-160.

SCHUMACHER, I. 2013. Political stability, corruption and trust in politicians. Economic Modelling, 31(1):359-369.

SEGAL, G. \& SUMMERS, A.B. 2002. Citizens' budget report: Improving performance and accountability in government. eason.org/files/78a6bc2717f984a2b9b783192f5d1bad.pdf [accessed June 2014].

SØREIDE, T. 2002. Corruption in public procurement: Causes, consequences and cures. Postterminalen. www.cmi.no > Publications > CMI Reports [accessed April 2013].

TAVARES, J. 2003. Does foreign aid corrupt? Economics Letters, 79(1):99-106.

TREISMAN, D. 2000. The causes of corruption: A cross-national study. Journal of Public Economics, 76(3):399-457.

TREISMAN, D. 2007. What have we learned about the causes of corruption from ten years of cross-national empirical research? Annual Review of Political Science, 10:211-244.

TRUEX, R. 2011. Corruption, attitudes, and education: Survey evidence from Nepal. World Development, 39(7):1133-1142.

VIAN, T. 2008. Review of corruption in the health sector: Theory, method and interventions. Health Policy and Planning, 23(2):83-94.

WANG, Y. 2005. Corruption and anti-corruption policy in today's China. Hitotsubashi Journal of Law and Politics, (33):1-5. http://hdl.handle.net/10086/8134 [accessed April 2013]. 


\section{Appendix}

Table A1

Correlation matrix

\begin{tabular}{|c|c|c|c|c|c|c|c|c|c|c|c|c|c|}
\hline & 1 & 2 & 3 & 4 & 5 & 6 & 7 & 8 & 9 & 10 & 11 & 12 & 13 \\
\hline Corruption (1) & 1 & & & & & & & & & & & & \\
\hline Economic prosperity (2) & $0.10^{*}$ & 1 & & & & & & & & & & & \\
\hline Primary enrolment (3) & $0.12^{*}$ & 0.01 & 1 & & & & & & & & & & \\
\hline Secondary enrolment (4) & $0.49^{*}$ & -0 & $0.57^{*}$ & 1 & & & & & & & & & \\
\hline Trade freedom (5) & $0.34^{*}$ & $0.14^{*}$ & $0.07^{*}$ & $0.19^{*}$ & 1 & & & & & & & & \\
\hline Population growth (6) & $-0.14^{*}$ & $0.27^{*}$ & 0.03 & $-0.19^{*}$ & -0.04 & 1 & & & & & & & \\
\hline Resource abundance (7) & $-0.36^{*}$ & -0.1 & $0.14^{*}$ & 0.04 & $-0.20^{*}$ & -0.05 & 1 & & & & & & \\
\hline Aid inflow (8) & 0.02 & 0.02 & $0.21^{*}$ & $0.15^{*}$ & $0.19^{*}$ & -0.04 & -0 & 1 & & & & & \\
\hline Bureaucrats' wages (9) & $0.53^{*}$ & 0.03 & $0.41^{*}$ & $0.72^{*}$ & $0.22^{*}$ & $-0.09^{*}$ & -0.1 & -0 & 1 & & & & \\
\hline Press freedom (10) & $-0.62^{*}$ & $-0.13^{*}$ & $0.14^{*}$ & $-0.28^{*}$ & $-0.33^{*}$ & $0.21^{*}$ & 0.05 & $-0.10^{*}$ & $-0.23^{*}$ & 1 & & & \\
\hline $\begin{array}{l}\text { Government effectiveness } \\
\text { (11) }\end{array}$ & $0.82^{*}$ & $0.11^{*}$ & 0.05 & $0.43^{*}$ & $0.46^{*}$ & -0.04 & $-0.48^{*}$ & $0.24^{*}$ & $0.50^{*}$ & $-0.62^{*}$ & 1 & & \\
\hline Regulatory quality (12) & $0.71^{*}$ & $0.12^{*}$ & 0.03 & $0.30^{*}$ & $0.53^{*}$ & 0.04 & $-0.44^{*}$ & $0.13^{*}$ & $0.36^{*}$ & $-0.69^{*}$ & $0.87^{*}$ & 1 & \\
\hline Rule of law (13) & -0.08 & 0.02 & $-0.27^{*}$ & $-0.38^{*}$ & $0.22^{*}$ & $0.40^{*}$ & -0.1 & $-0.27^{*}$ & 0.03 & $-0.18^{*}$ & $0.19^{*}$ & $0.39^{*}$ & 1 \\
\hline
\end{tabular}

Note: ${ }^{*} p<0.05$

Table A1

Correlation matrix (continued)

\begin{tabular}{|l|c|c|c|c|c|c|c|}
\hline & 14 & 15 & 16 & 17 & 18 & 19 & 20 \\
\hline Property rights (14) & 1 & & & & & & \\
\hline Economic freedom (15) & $0.67^{*}$ & 1 & & & & & \\
\hline Size of government (16) & -0.04 & 0.00 & 1 & & & & \\
\hline Contemporary democracy (17) & -0.04 & -0.1 & -0.11 & 1 & & & \\
\hline Bureaucratic cost (18) & 0.00 & -0.00 & -0.01 & $-0.17^{\star}$ & 1 & & \\
\hline Ethnic fractionalisation (19) & $0.29^{*}$ & $0.31^{*}$ & 0.01 & -0.11 & 0.08 & 1 & \\
\hline British colony (20) & 0.05 & 0.03 & -0.08 & 0.05 & $-0.38^{*}$ & -0.10 & 1 \\
\hline
\end{tabular}

Note: * $p<0.05$ 